ISSN: 2526-7884

Editor: Prof. Dr. Marconi Freitas da Costa

E-mail: cbr@ufpe.br
Avaliação: Double blind review

Recebido: 29 de março de 2021

Aprovado: 01 de setembro de 2021

\title{
ANÁLISE DO COMPORTAMENTO DO CONSUMIDOR NO PERÍODO DE CRISE E DISSEMINAÇÃO DA COVID-19 NO BRASIL
}

Analysis of the Consumer's Behavior in the Period of the Crisis and Dissemination of Covid-19 in Brazil

\author{
Livia Mendes Carneiro ${ }^{1}$ \\ ORCID: http://orcid.org/0000-0002-9283-1770 \\ E-mail: liv.aimendes@gmail.com \\ Eveline Barbosa Silva Carvalho ${ }^{1}$ \\ ORCID: http://orcid.org/0000-0002-3926-5255 \\ E-mail: eveline@ufc.br \\ ${ }^{1}$ Universidade Federal do Ceará, Ceará, Brasil
}

\begin{abstract}
Resumo
A presente pesquisa tem natureza quantitativa e transversal, e o objetivo de analisar o comportamento dos consumidores relativo ao aumento de preços praticados pelas farmácias e/ou pontos de vendas especializados, assim como o de empresas no período e após a crise e disseminação da covid 19 no Brasil. Analisou-se, também, como o sentimento de justiça, "fairness", por parte dos consumidores, pode representar uma restrição na busca de lucro das empresas, no curto e no longo prazo. 0 estudo se deu através da pesquisa de recolhimento de dados primários sobre a psicologia do consumidor e a sua tomada de decisão, e os dados recolhidos para análise
\end{abstract}

\begin{abstract}
This research is quantitative and transversal, and the objective is to analyze the behavior of consumers regarding the increase in prices practiced by pharmacies and/or specialized sales points, as well as that of companies in the period and after the crisis and dissemination of the covid 19 in Brazil. It was also analyzed how the feeling of justice, "fairness", on the part of the consumers, can represent a restriction in the search for profit by the companies, in the short and long term. This study was carried out through a survey of primary data collection on consumer's psychology and its decision-making, and the data collected for analysis were tabulated and
\end{abstract}


foram tabulados e analisados por estatística descritiva. A associação de variáveis foi verificada por meio do teste Qui-quadrado, adotando-se um nível de significância de $10 \%$. A pesquisa foi inspirada no estudo de Kahneman, Knetsch e Thaler (1986a) sobre a percepção de justiça dos consumidores e como "fairness", esse sentimento de justiça, pode mostrar-se uma barreira à busca pelo lucro. Os resultados revelaram que o contexto no qual as pessoas estão inseridas, no caso, uma catástrofe sanitária, influenciam na percepção destas e na sua disposição quanto a "punir" empresas que, nesse período de crise e disseminação da covid- 19, tiveram uma atitude considerada "injusta" na sua política de preços.

Palavras-chave: Análise comportamental; Psicologia do consumidor; Covid-19. analyzed using descriptive statistics. The association of variables was verified using the chi-square test, adopting a significance level of $10 \%$. The research was inspired by the study of Kahneman, Knetsch and Thaler (1986a) on consumers' perception of fairness and how "fairness", this feeling of justice, can prove to be a barrier to the pursuit of profit. The results revealed that the context in which people are inserted, in this case, a sanitary catastrophe, influence their perception and their willingness to "punish" companies that, in this period of crisis and dissemination of covid- 19, had an attitude. considered "unfair" in its pricing policy.

Keywords: Behavioral economic analysis; Consumer psychology; Covid-19.

This work is licensed under a Creative Commons Attribution 4.0 International License.

\section{INTRODUÇÃO}

Os primeiros registros de casos do posterior surto de pneumonia viral no outono de 2019, proveniente do surgimento de um novo coronavírus zoanthroponous humano, o vírus SARS-CoV-2, foram registrados na cidade de Wuhan, província de Hubei, localizada na China (Lvov \& Alkhovsky, 2020). O agente microbiano altamente contagioso, resultado de eventos evolutivos que são transmitidos para humanos diretamente ou através de hospedeiros vertebrados intermediários, gotículas, objetos contaminados e também o contato entre humanos (Bchetnia et al, 2020; Lu et al., 2020; Lima et al., 2020).

De risco e gravidade ainda pouco conhecidos, em janeiro de 2020, mais de 2000 casos de infecções já haviam sido confirmados. Pesquisadores chineses identificaram como patógeno causador um novo coronavírus (Lu et al., 2020), sendo, pois, um agente etiológico de uma síndrome respiratória aguda grave que posteriormente convencionou-se chamar de COVID-19 (Cavalcante et al., 2020). Em alguns pacientes, entretanto, o agente infeccionado pode apresentar apenas uma síndrome respiratória leve. De um modo geral, a doença pode ser resolvida de forma fácil, embora, ela, também, possa ser mortal, apresentando uma taxa de letalidade de 2\% (Xu et al., 2020).

0 vírus vem demonstrando ter maior letalidade em pacientes idosos e com comorbidades. 0 SARS-CoV-2 pode se espalhar principalmente através de gotículas de saliva ou na forma de secreção nasal, no ato de uma pessoa infectada tossir, espirrar ou infectar superfícies em locais públicos World Health Organization [WHO] (2020).

Após o primeiro caso ser documentado na China, é suposto que a primeira pessoa infectada tenha estado no mercado de frutos do mar, onde, também, vários animais não aquáticos, se encontravam à venda antes do surto, sendo presumível que a transmissão tenha ocorrido através de morcegos, que são reservatórios de diversos coronavírus (Latinne et al., 2020) os típicos casos de coronavírus que infectam humanos conhecidos por serem zoonóticos, ou de origem animal, vírus de RNA causadores de doenças respiratórias e entéricas, tendo a patogenicidade variável ao infectar humanos e animais (Lu et al., 2020).

Com o intenso trânsito de pessoas e os fluxos migratórios diários em Wuhan, e a possibilidade de conexões via transporte com o mundo inteiro, o espraiamento do novo vírus ocorreu em questão de meses. Vários casos iam sendo registrados em outras regiões dentro da China, além de outros em diversos países asiáticos, fazendo com que já em fevereiro de 2020, registros da doença começassem a 
aparecer na Europa e nos Estados Unidos (Lu et al. 2020; Rothan \& Byrareddy, 2020; Lima et al., 2020).

À vista disso, para manter a população e o corpo médico informados, WHO, através do Public health and social measures, elaborou uma série de medidas preventivas e de proteção pessoal, recomendando a aquisição de acessórios e produtos que possibilitassem a higiene das mãos e das partes de contato com o rosto, orientou, também, a respeito de uma etiqueta respiratória e o uso de máscaras, além da necessidade de se manter constantemente os ambientes limpos, a regular desinfecção de superfícies e maior ventilação em locais fechados. Também estavam incluídas medidas como o distanciamento social, a limitação de aglomerações públicas e reuniões, o isolamento de pessoas infectadas etc. (WHO, 2020).

No Brasil, apenas no mês de fevereiro é que começaram a surgir os primeiros casos de pessoas infectadas pela nova patogênese da Covid-19 (LIMA et al., 2020). 0 medo do novo vírus e as incertezas trazidas pelas ainda incertas formas de tratamento, assim como as possíveis consequências e danos colaterais à saúde, trouxe a necessidade de a população aplicar coletivamente e individualmente as medidas de proteção orientadas pela OMS, adquirindo produtos de proteção e higiene pessoais (Cronologia, 2020, Cronologia da Covid-19 no Brasil).

Além disso, foi-se estipulado, também, a implementação de protocolos de bloqueio total, campanhas de informação, mudanças no comportamento social com a obrigatoriedade do uso de máscara facial, distanciamento entre as pessoas, a não permissão de aglomerações públicas e privadas, assim como o isolamento de infectados. Todas essas medidas se mostraram intervenções não farmacológicas eficazes (Cavalcante et al., 2020).

A necessidade do uso de materiais para higiene e proteção fez com que a demanda por determinados produtos crescesse de forma rápida e imprevisível para muitos ofertantes, que mantinham, até o momento, estoques correspondentes à necessidade regular dos consumidores em relação a produtos como o álcool em gel, máscara de proteção facial, papel higiênico, entre outros.

Com o aumento rápido da demanda por tais produtos, a tendência foi de alta nos preços em relação a períodos passados. A teoria do consumidor nos modelos canônicos de economia relativiza esse fenômeno, de rápida inflação, como um processo natural decorrente de um excedente de demanda dado uma oferta estrita, o que na curva de demanda individual desses bens (Preço $\mathrm{x}$ Quantidade), representaria, segundo a teoria clássica, um aumento de preços no curto prazo.

Nessa perspectiva, Varian (2006) aponta que a escolha, pelo consumidor, de sua cesta de bens de consumo é determinada a partir de quando, onde e sob que circunstâncias os bens podem estar disponíveis. Ora, as circunstâncias do consumo em determinados espaços e tempos podem ser modificadas e a demanda dos produtos pode se fazer de extrema necessidade, o que para o ofertante pode representar uma vantagem no seu interesse final de lucro.

Menger (1840-1921) explica os preços na relação entre oferta e demanda, sendo a utilidade como determinante último dos preços dos bens de consumo. Dessa forma, quando a utilidade marginal recebida pelo consumidor ao consumir determinado produto era menor que o seu preço, o consumidor deixaria de realizar a compra (Hunt \& Lautzenheiser, 2013).

Num cenário de catástrofe representada pela pandemia da Covid-19, as necessidades dos consumidores se voltaram para bens de primeira necessidade como os bens que servem para a proteção e prevenção em relação à doença causadora da pandemia, no que Varian (2006) entende como o consumo ocorrendo dado o grau de desejabilidade do consumidor em relação a determinados produtos, sendo, portanto, uma cesta de consumo com estes bens mais desejável do que outra.

Um aumento da demanda de mercado, como componente importante na determinação dos preços, possibilita uma certa flexibilidade do ofertante quanto aos preços aplicados aos consumidores, em relação aos custos das firmas, da necessidade de remuneração dos seus fatores de produção. Embora, com um aumento da demanda, o poder de mercado das firmas aumenta em relação aos preços aplicados, que podem ou não, corresponder aos preços de custo dos produtos demandados, o que resultaria um aumento nos lucros.

Contudo, Kahneman et al. (1986a; 1986b) avaliam que neste cálculo, a percepção dos consumidores aos preços aplicados, em cenários de crise e desastres, pode significar uma resposta destes para com os ofertantes, ou seja, as firmas que são consideradas com um comportamento injusto 
são mais suscetíveis a serem punidas, o que pode afetar os lucros no longo prazo. Logo, a preocupação dos ofertantes, nesses cenários, deve ir além da maximização de seus lucros no curto prazo.

As circunstâncias nas quais o preço de um produto é percebido pode influenciar determinadas decisões de consumo. Na economia comportamental, esse conceito é relacionado ao ponto de referência, em que os ganhos e as perdas têm pesos diferentes para o consumidor, assim como a subordinação à forma, no que pese o contexto dado ao problema (Shefrin, 2003).

Ademais, num cenário de crise e catástrofe, os consumidores sofrem influências cognitivas diversas, sendo, portanto, passível de ser aceito a postulação de que os consumidores aceitem menos os aumentos de preços como resultado de um crescimento da demanda de curto prazo, do que no caso de um aumento nos custos de produção. Essas constatações são dificilmente explicadas pela simples maximização da utilidade em que se apoia a microeconomia tradicional das ciências econômicas (Pindyck \& Rubinfeld, 2006).

Nosso estudo consiste numa pesquisa em que recolhemos dados primários sobre a psicologia do consumidor e a sua tomada de decisão. Devido às subjetividades dos consumidores, assim como as formações de mercado, estruturas de mercado, a presente pesquisa é limitada pela percepção estática do consumidor no presente momento na qual foi aplicada assim como pelo tamanho da amostra estudada. Outra limitação inerente da pesquisa, está no formulário de perguntas desta que limita, em algumas questões, as respostas em uma forma binária.

Os parâmetros de análise desta pesquisa são baseados nos achados nos estudos de Kahneman et al. (1986a) e de Thaler (1999b), que discute como a concepção de justiça pode influenciar a decisão de consumo das pessoas, de modo que, ao se deparar com situações de "catástrofe", como desastres naturais, ou enchentes, ou queimadas, em que os fornecedores de determinados produtos aumentam o seu poder de mercado em virtude da limitação da oferta, no curto prazo, e o aumento vertiginoso da demanda, conseguem determinar preços, sem, contudo, haver uma correspondência, necessariamente, nos custos destes produtos. Ou seja, o aumento no preço se dá, primordialmente, pela limitação da oferta e o aumento da demanda, advindo desse poder de mercado obtido a partir da situação adversa da catástrofe.

Nosso estudo, além de analisar as questões abordadas pelos estudos de Kahneman et al. (1986a) e de Thaler (1999b) no contexto da Covid-19 no Brasil, tentamos trazer novos questionamentos aos entrevistados, assim como fazemos uma estatística em que associamos as variáveis sócio-demográficas dos entrevistados às suas respostas no questionário que aplicamos. 0 contexto da Covid-19 no Brasil, houve um aumento nos preços de produtos de higiene e proteção em farmácias e/ou pontos de vendas especializados, assim como o de empresas que praticaram um aumento de preços.

Ademais, constatamos que ocorreu uma mudança nos hábitos de consumo dos consumidores, nesse período, e que, os consumidores, ao serem colocados na posição de ofertantes, reduziriam os preços dos seus produtos, o que denota uma perspectiva de uma psicologia comunitária por parte destes.

Dessa forma, o presente estudo teve como objetivo analisar, dado o cenário de crise sanitária da Covid-19, em escala mundial, e da necessidade de proteção individual e coletiva, o comportamento dos consumidores e sua percepção em relação ao aumento de preços praticado pelas farmácias e/ou pontos de vendas especializados, assim como o de empresas no período e após a crise e disseminação da Covid-19 no Brasil, analisando, também, como o sentimento de justiça, por parte destes consumidores, pode representar uma restrição na busca de lucro, no curto e no longo prazo.

Dividimos este artigo em seis seções, sendo na seção 1, abordamos uma breve introdução sobre o contexto da covid-19 no mundo e no Brasil, assim como a apresentação da análise da economia comportamental neste cenário. Na seção 2, discutiremos, de maneira breve, um paralelo a partir do debate sobre a psicologia do consumidor a partir da ótica nos estudos econômicos dos modelos canônicos e comportamentais da economia. Na seção 3, serão apresentados o método de análise e coleta de dados. Na seção 4, serão mostrados os resultados obtidos e os dados coletados, assim como a estatística e a associação das variáveis. Na seção 5 , apresentaremos uma discussão a respeito dos dados obtidos e na seção 6 e última seção, serão apresentadas as considerações finais. 


\section{TEORIA CLÁSSICA E A ANÁLISE DO COMPORTAMENTO DO CONSUMIDOR}

Para Simonsen (1988) a teoria tradicional do comportamento do consumidor, atribui a hipótese na qual "os indivíduos distribuem racionalmente suas despesas dentro de suas limitações orçamentárias, de modo a delas extrair o máximo de satisfação". A nova lógica que nasce com o despontar do sistema capitalista, de um ponto de vista histórico e filosófico, fazem com que os ganhos monetários, o gozo do dinheiro recebido, o individualismo e o hedonismo tenham um fim em si mesmos, sendo a utilidade ou felicidade do indivíduo, como irracional e um todo transcendente, tornando o agente em função do ganho (Weber, 2004). 0 indivíduo, portanto, já nasceria dentro dos parâmetros do sistema e imerso em sua lógica maximizadora, criado e educado de forma a se tornar sujeito econômico.

Jevons (1835-1882), em seu utilitarismo econômico, preconizava que as pessoas, sem distinção, possuem apenas duas características: a primeira era que as pessoas são possuidoras de utilidade e a extração desta ocorreria a partir do consumo de mercadorias e a segunda era que todas as pessoas são maximizadoras racionais e calculistas. Estas características tornavam- os agentes econômicos (Hunt \& Lautzenheiser, 2013).

Os pontos centrais das hipóteses dos modelos canônicos de economia focado na escolha do consumidor partem de uma hipótese de racionalidade em que os parâmetros de análise perpassam a nossa de uma medida de utilidade, ou uma escala ordinal de preferências do consumidor, em que o consumidor tende a procurar obter o máximo de utilidade, situando-se no ponto mais alto da curva de nível, tangenciada por sua restrição orçamentária. Os pressupostos psicológicos da teoria tradicional da economia são deveras debatíveis, sendo, portanto, suas hipóteses, sob vários aspectos, simplistas (Simonsen, 1988).

Fehr e Schmidt (2003) apontam que "a teoria da utilidade clássica assume que um tomador de decisão tem preferências sobre as alocações de material resultados (por exemplo, bens) e que essas preferências satisfazem alguma "racionalidade" ou "consistência" requisitos, como completude e transitividade". Para Smith (2000), a conotação de racionalidade dos agentes não se põe como criação de um ser humano impassível ao erro, mas sim como a hipótese de racionalidade sendo a capacidade lógica e superior do ser humano de pensar e aprender com os erros, embora seja inconcebível o cometimento de erros sucessivos sistematicamente.

[...] De acordo com Simonsen (1988, p.3), a concepção de comportamento racional pode ser interpretada de duas maneiras: Na primeira interpretação, pode-se conferir à palavra racional uma conotação ética e objetiva, em que o agente se orientaria por este padrão de conduta. Embora, tal interpretação possa envolver difíceis juízos de valor, na medida em que, seria empiricamente inaceitável, "pois a prodigalidade e a imprevidência são características muito espalhadas no gênero humano".

Na segunda interpretação, é possível abstrair qualquer conotação ética ou objetiva da ideia de comportamento racional, sendo esta apenas uma racionalização lógica matemática de preferências do consumidor associadas a derivadas parciais em que o consumidor escolhe sua cesta de consumo visando a maximização de sua utilidade dadas as suas limitações orçamentárias. Dessa forma, "a ideia de comportamento racional se transforma numa espécie de truísmo" (Simonsen, 1988, p. 4)

Em todo caso, o paradigma da escolha racional está relacionado ao custo subjetivo de exploração das possíveis opções de escolha e do descobrimento do que fazer, sendo estes parte do problema da escolha racional e do tomador de decisão. Dessa forma, o custo da decisão é o custo da atenção, do leque de informação, do monitoramento do pensar, da análise e da ação, determinantes do processo de decisão (Smith, 2000).

0 comportamento dos indivíduos às vezes contradiz as premissas sobre as quais nosso modelo básico para a escolha do consumidor se apoiou. Talvez compreendêssemos melhor as escolhas feitas pelos consumidores, as características da demanda e as decisões tomadas pelas empresas se incorporássemos premissas mais realistas e detalhadas quanto ao comportamento humano (Pindyck \& Rubinfeld, 2006, p. 153). 
Os estudos da economia comportamental abordam a discussão a respeito da tomada de decisão dos agentes econômicos de um ponto de vista que vai de encontro aos axiomas1 da teoria da utilidade esperada e ao pressuposto de que as previsões dos indivíduos são unbiased em relação ao futuro (Thaler, 1999), ou seja, pressupostos que não se configuram como uma explicação satisfatória para as nuances presentes na forma como empiricamente os indivíduos exercem a sua tomada de decisão em um contexto de liberdade e incertezas.

A partir dos estudos, principalmente, de Kahneman (2012), constatou-se que há, no indivíduo, a recorrência de fatores cognitivos, nem sempre perceptíveis, que os induzem a intuições falhas, baseadas em percepções práticas comumente chamadas de heurísticas, o que torna os indivíduos vulneráveis a erros e vieses. Dessa forma, os agentes econômicos na sua tomada de decisão seriam, portanto, influenciados por esses vieses cognitivos. Fica aparente a diferença entre a psicologia desenvolvida pela análise do homo economicus ou 'Econs' e os padrões de decisão em testes empíricos desenvolvidos no âmbito da análise comportamental (Shefrin \& Statman, 1985).

Logo, o ser humano, mesmo no papel de consumidor, seria um agente econômico com a percepção, dos acontecimentos, limitada pela quantidade de informações disponíveis e as quais ele teria acesso, o que representaria um fator limitador de escolha. Baseado nisso, haveria, no indivíduo, uma impossibilidade de se fazer escolhas perfeitamente consistentes e lógicas, assim como haveria uma aversão à perda maior que sua realização no ganho. Esses achados das análises da economia comportamental contrastam frontalmente com as hipóteses de racionalização defendidas nos modelos de economia clássica (Kahneman, 2012; Shefrin e Statman, 1985).

\section{MÉTODO}

A nossa pesquisa é de natureza quantitativa e transversal e foi inspirada no estudo de Kahneman et al. (1986a) em que se é analisado a percepção das pessoas quanto a concepção de justiça e como o "fairness", esse sentimento de justiça, pode mostrar-se uma barreira à busca pelo lucro. Kahneman et al. (1986a) faz uma pesquisa primária em que se é perguntado pelo telefone aos entrevistados várias perguntas a respeito de cenários de catástrofe em que se necessita o consumo de bens importantes naquele contexto, mas os ofertantes acabam que por aumentando os preços de seus produtos em virtude, principalmente, da limitação da oferta e do aumento da demanda. Como exemplo, dar-se a necessidade da compra de uma pá num contexto de uma nevasca muito forte.

\section{Dados}

Para o recolhimento de dados para a nossa pesquisa, confeccionamos um questionário na plataforma Google® Formulários e divulgamos de forma online a um grupo variado de pessoas por meio de três redes sociais, quais sejam: Instagram@, Facebook@e Whatsapp@. A pesquisa teve alcance nacional, ficando disponível para os respondentes no período de 29 de abril a 15 de setembro de 2020, sendo este o prazo o da coleta de dados. Neste período, grande parte da população ainda se encontrava em quarentena decretada pelos governos estaduais no Brasil.

0 questionário, do tipo opinião e sem a identificação dos participantes, constava de 13 perguntas fechadas e ordenadas (Apêndice A). Destas, de Q11 a Q13 eram sócio-demográficas, em duas, Q2 e Q3, demonstramos o aumento de preços nas farmácias e/ou os pontos de venda especializados cobravam por uma caixa de máscaras, 50 uni. tripla c/ elástico, $\mathrm{R} \$ 4,50$. Após a crise e disseminação da Covid-19, a mesma caixa de máscaras, 50 uni. tripla c/ elástico custa $\mathrm{R} \$ 82,50$. Ainda em relação ao álcool gel, cobravam por $420 \mathrm{ml}$ de álcool gel 70 o valor de $\mathrm{R} \$ 12,00$. Após a crise e disseminação da Covid-19, o mesmo frasco de álcool gel 70 está custando $\mathrm{R} \$ 45,00$.

A escolha destes dois produtos, tanto a caixa de máscaras quanto o álcool em gel pelo fato de terem se mostrado produtos mais recomendados para a proteção pessoal das pessoas no período de crise e disseminação da Covid-19 no Brasil, e foi amplamente recomendado pela WHO (2020).

As questões Q4 a Q10 eram a respeito da percepção dos entrevistados em relação à alteração de preços por parte de empresas e como estes reagiriam a estas alterações. A pergunta (Q9) colocava o entrevistado em uma posição diferenciada da de consumidor, ou seja, o entrevistado na posição de 
ofertante. Estas perguntas foram apresentadas ao grupo de entrevistados com respostas obtidas de forma aleatória.

Nas perguntas de Q5 a Q9, as respostas foram escolhidas para serem dicotômicas, em decorrência do propósito deste estudo, tanto para facilitar a análise quanto mostrarem-se mais adequadas dado a natureza das perguntas serem questões, de fato, de problemas claros e de opiniões bem definidas sobre a percepção dos respondentes, pressupondo a forma como os mesmos portar-seiam no período de crise e disseminação da Covid-19, e portar-se-ão depois.

Ademais, essa característica de dicotomia nas respostas possibilitou uma rapidez e facilidade na aplicação, processo e análise, menor risco de parcialidade e indecisão do entrevistador, sendo, portanto, mais objetivas (Mattar, 1994)

A ordenação das perguntas foi disposta de acordo com uma linha de raciocínio que facilitasse o entendimento dos respondentes em relação ao cenário proposto no questionário, de modo que o respondente fosse colocado a se posicionar em relação às questões de Q5 a Q9 baseados nos, em alguma medida, nos cenários propostos nas questões Q2 a Q4. É importante destacar que as respostas dos participantes às questões (Qs) foram analisadas separadamente a partir das informações obtidas no questionário aplicado.

\section{Estatística}

Os dados recolhidos para análise foram tabulados e analisados por estatística descritiva frequência absoluta, porcentagens - na planilha eletrônica EXCEL Microsoft $®$ Excel ${ }^{\circledR} 2019$ MSO (16.0.14026.20294) 64 bits. A associação das variáveis sócio-demográficas com as perguntas do questionário (Q1 a Q10) foi verificada por meio do teste com distribuição Qui-quadrado, adotando-se um nível de significância de $10 \%$. A amostra mostrou-se significativa, contudo, pecou na extensão, o que tornou a estatística dos resultados, apenas, relevantes ao nível de $10 \%$. Amostras maiores ajudam a obter inferências estatísticas mais confiáveis.

\section{RESULTADOS}

Nesta seção serão apresentados os dados colhidos para a amostra e análise, assim como os resultados obtidos da associação das variáveis sóciodemográficas com as perguntas do questionário.

\section{Resultados sociodemográficos (Q11 a Q13)}

Em relação ao gênero, o questionário tratou o dado de forma binária, ou seja, feminino e masculino. Assim, constatou-se que a participação do gênero feminino nesta pesquisa foi maior, totalizando $54,23 \%$ da amostra.

Em relação à renda, optou-se por conduzir o entrevistado ao parâmetro de intervalo de renda em relação ao salário mínimo vigente no país no ano de 20202. No Gráfico 2 são apresentadas as faixas de rendimentos dos participantes da pesquisa, sendo possível inferir que a amostra teve maior participação dos que apresentavam uma renda no intervalo de um a três salários mínimos.

No tocante à idade dos participantes da pesquisa, pode-se constatar que o intervalo de 18 - 25 anos foi o de maior incidência na amostra recolhida, com participação de 53,52\% do total da amostra. Dessa forma, a partir dos dados auferidos do recorte sócio-demográfico dos participantes da pesquisa, é possível constatar que foram prevalecentes o gênero feminino $(54,23 \%)$, o nível de renda de um a três salários mínimos (40,85\%), na faixa etária dos 18 - 25 anos (53,52\%).

\section{Resultados das questões (Q1 a Q10)}

A Tabela 1 apresenta as proporções das repostas dos respondentes em relação às questões Q2 e Q3 que apresentavam as situações de mudança nos preços no período de crise e disseminação da Covid-19 no ano de 2020 comparativamente aos preços destes produtos vigentes no ano anterior (2019).

As respostas das referidas questões configuram-se em medida ordinal, sendo as duas primeiras uma representação favorável que indicam que os entrevistados julgaram a ação aceitável, a 
terceira demonstra uma indiferença em relação à mudança de preço e as duas últimas sendo desfavoráveis, visto que o entrevistado considerou a ação injusta.

\section{Tabela 1}

Proporção em relação à percepção de justiça quanto à diferença de preços dos bens de consumo caixa de máscaras e álcool gel 70 nos anos de 2019 e 2020 (período da crise e disseminação da covid-19).

\begin{tabular}{r|r|r}
\hline \multicolumn{1}{c|}{ Respostas } & \multicolumn{1}{|c|}{ Q2 (\%) } & \multicolumn{1}{c}{ Q3 (\%) } \\
\hline Muito Justo & 2,8 & 1,4 \\
\hline Justo & 7 & 9,15 \\
\hline Indiferente & 3,5 & 3,5 \\
\hline Injusto & 30,3 & 31 \\
\hline Muito Injusto & 56,3 & 54,9 \\
\hline
\end{tabular}

Fonte: Pesquisa sobre psicologia do consumidor Covid 19 - Elaborada pelas autoras

Na questão Q4, 95,07\% ( $n=135)$ dos respondentes afirmaram que optariam por procurar um produto similar de uma empresa concorrente, enquanto, apenas, 4,93\% $(n=7)$ dos respondentes continuariam comprando estes produtos normalmente.

O Gráfico 2 é baseado nas respostas obtidas na questão Q10 e apresenta a proporção de respondentes referentes a como eles agirão, após a crise, em relação às empresas que aumentaram o valor de seus produtos no período da crise.

\section{Gráfico 2}

Proporção em relação a como agirão os respondentes frente às empresas que aumentaram os preços de seus produtos no período de crise e disseminação da covid-19.

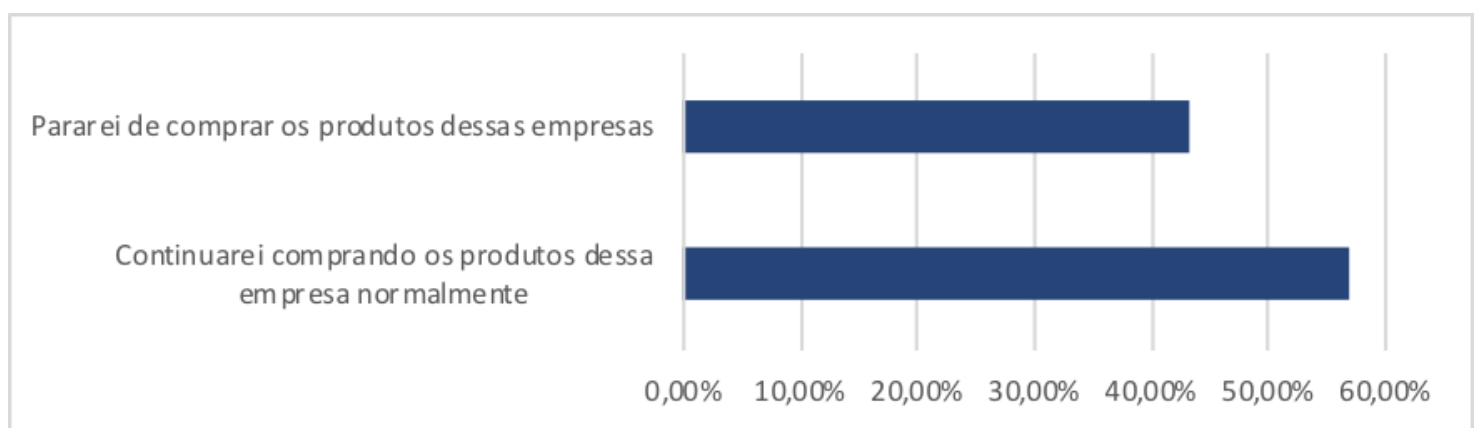

Fonte: Pesquisa sobre psicologia do consumidor Covid 19 - Elaborado pelas autoras

Na Tabela 2 são apresentados os resultados relativos às questões Q5 a Q8 em que é analisado o comportamento dos respondentes frente a atitude destes para com as empresas a partir das possíveis políticas de preços adotadas no período de crise e disseminação da Covid-19. No caso da questão Q9, o respondente foi tirado da posição de consumidor e posto na perspectiva de dono da empresa fornecedora dos bens de primeira necessidade. 
Tabela 2

Disposição de consumo dos respondentes frente à atitude das empresas em relação a diferentes políticas de preços adotadas pelas empresas

\begin{tabular}{|c|c|c|c|c|}
\hline \multirow{2}{*}{ Questões } & \multicolumn{2}{|c|}{ Sim } & \multicolumn{2}{|c|}{ Não } \\
\hline & $\mathbf{n}$ & $\%$ & $\mathbf{n}$ & $\%$ \\
\hline $\begin{array}{l}\text { Q5. Você daria preferência a uma empresa que faz } \\
\text { promoções e/ou vende seus produtos mais baratos nesse } \\
\text { período de crise e disseminação da Covid-19? }\end{array}$ & 140 & 98,6 & 2 & 1,4 \\
\hline $\begin{array}{l}\text { Q6. Após a crise e disseminação da Covid-19, você } \\
\text { continuaria adquirindo produtos de empresas que } \\
\text { aumentaram os preços de seus produtos no momento da } \\
\text { crise e disseminação da covid-19? }\end{array}$ & 56 & 39,5 & 86 & 60,5 \\
\hline $\begin{array}{l}\text { Q7. Após a crise e disseminação da Covid-19, você teria } \\
\text { preferência em adquirir produtos de empresas que } \\
\text { baixaram os preços de seus produtos no momento da crise e } \\
\text { disseminação da covid-19? }\end{array}$ & 131 & 92,2 & 11 & 7,8 \\
\hline $\begin{array}{l}\text { Q8. Após a crise e disseminação da Covid-19, você teria } \\
\text { preferência em adquirir produtos de empresas que } \\
\text { aumentaram os preços de seus produtos no momento da } \\
\text { crise e disseminação da covid-19? }\end{array}$ & 11 & 7,8 & 131 & 92,2 \\
\hline $\begin{array}{l}\text { Q9. Se você fosse dono de uma empresa, no período de crise } \\
\text { e disseminação da Covid-19, em relação aos bens de } \\
\text { primeira necessidade, você reduziria os preços dos produtos } \\
\text { da sua empresa, reduzindo, assim, seu lucro? }\end{array}$ & 97 & 68,3 & 45 & 31,7 \\
\hline
\end{tabular}

\section{Resultados da estatística de associação das variáveis}

Quanto à associação de variáveis, analisou-se as perguntas em relação recorte de gênero, renda e faixa etária dos entrevistados. Esses achados estão descritos nas Tabelas a seguir.

Tabela 3

Associação entre as respostas do questionário em relação ao gênero dos participantes

\begin{tabular}{|c|c|c|c|c|c|}
\hline \multirow{2}{*}{ Variáveis } & \multicolumn{2}{|c|}{ Gênero Feminino } & \multicolumn{2}{|c|}{$\begin{array}{c}\text { Gênero } \\
\text { Masculino }\end{array}$} & \multirow{2}{*}{ Valor - p } \\
\hline & $\mathbf{n}$ & $\%$ & $\mathbf{N}$ & $\%$ & \\
\hline $\begin{array}{l}\text { Q1. Na sua opinião, seus hábitos de consumo após a } \\
\text { estipulação da quarentena foram afetados? }\end{array}$ & & & & & 0,888 \\
\hline Muito afetados & 27 & 35,06 & 20 & 30,76 & \\
\hline Afetados & 35 & 45,45 & 30 & 46,15 & \\
\hline Pouco Afetados & 13 & 16,88 & 12 & 18,46 & \\
\hline Não foram afetados & 2 & 2,59 & 3 & 4,61 & \\
\hline $\begin{array}{l}\text { Q2. No ano passado, as farmácias e/ou os pontos de venda } \\
\text { especializados cobravam por uma caixa de máscaras, } 50 \\
\text { uni. tripla c/ elástico, } R \$ 4,50 \text {. Após a crise e disseminação } \\
\text { da Covid-19, a mesma caixa de máscaras, } 50 \text { uni. tripla c/ } \\
\text { elástico custa } R \$ 82,50.0 \text { que você acha dos preços } \\
\text { cobrados pela caixa de máscaras triplas c/ elástico nesse } \\
\text { período de crise e disseminação da Covid-19? }\end{array}$ & & & & & 0,044 \\
\hline Muito Justo & 1 & 1,3 & 3 & 4,62 & \\
\hline Justo & 2 & 2,6 & 8 & 12,31 & \\
\hline
\end{tabular}




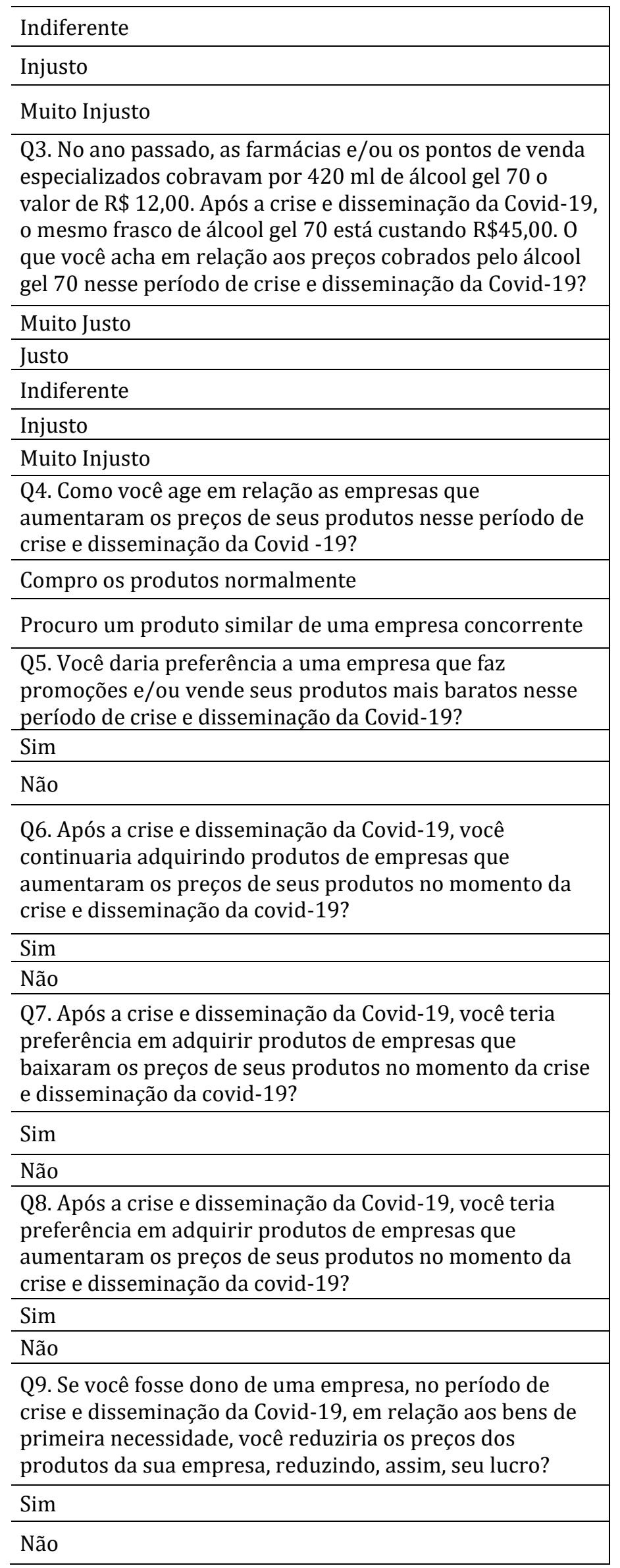

$\begin{array}{ccc}100 & 63 & 96,92 \\ & 2 & 3,08\end{array}$

$\begin{array}{llll}56 & 72,72 & 40 & 61,53 \\ 21 & 27,27 & 25 & 38,46\end{array}$


Q10. Como você agirá, após o término do período de crise e disseminação da Covid-19, em relação as empresas que nesse período aumentaram o preço dos seus produtos?

\begin{tabular}{l|llll}
$\begin{array}{l}\text { Continuarei comprando os produtos dessas empresas } \\
\text { normalmente }\end{array}$ & 31 & 40,26 & 31 & 47,69 \\
\cline { 1 - 2 } Pararei de comprar os produtos dessas empresas & 46 & 59,74 & 34 & 52,31 \\
\hline Teste Qui-quadrado & & & & \\
\hline
\end{tabular}

Fonte: Pesquisa sobre psicologia do consumidor Covid 19 - Elaborada pelas autoras

Tabela 4

Associação entre as respostas do questionário em relação a renda dos participantes

\begin{tabular}{|c|c|c|c|c|c|c|c|c|c|c|c|}
\hline \multirow[t]{2}{*}{ Variáveis } & \multicolumn{2}{|c|}{$\begin{array}{c}\text { Menor } \\
\text { que } 1\end{array}$} & \multicolumn{2}{|c|}{ De 1 a 3} & \multicolumn{2}{|c|}{ De 3 a 6} & \multicolumn{2}{|c|}{$\begin{array}{c}\text { De } 6 \text { a } \\
10\end{array}$} & \multicolumn{2}{|c|}{$\begin{array}{c}\text { Acima } \\
\text { de } 10\end{array}$} & \multirow[t]{2}{*}{ Valor - p } \\
\hline & $\mathbf{n}$ & $\%$ & $\mathbf{n}$ & $\%$ & $\mathbf{n}$ & $\%$ & $\mathbf{n}$ & $\%$ & $\mathbf{n}$ & $\%$ & \\
\hline $\begin{array}{l}\text { Q1. Na sua opinião, seus hábitos de consumo } \\
\text { após a estipulação da quarentena foram } \\
\text { afetados? }\end{array}$ & \multirow{6}{*}{$\begin{array}{c}12 \\
13 \\
9 \\
1\end{array}$} & \multirow{6}{*}{$\begin{array}{c}34,28 \\
37,14 \\
25,71 \\
2,85\end{array}$} & \multirow{6}{*}{$\begin{array}{c}24 \\
27 \\
8\end{array}$} & \multirow{6}{*}{$\begin{array}{l}40,67 \\
45,76 \\
13,55\end{array}$} & \multirow{3}{*}{$\begin{array}{c}6 \\
22\end{array}$} & \multirow[b]{2}{*}{18,8} & \multirow[b]{2}{*}{3} & \multirow[b]{2}{*}{30} & \multirow[b]{2}{*}{2} & \multirow[b]{2}{*}{25} & \multirow[t]{6}{*}{0,058} \\
\hline Muito afetados & & & & & & & & & & & \\
\hline Afetados & & & & & & 68,8 & 3 & 30 & 3 & 37,5 & \\
\hline Pouco Afetados & & & & & 3 & 9,37 & 2 & 20 & 2 & 25 & \\
\hline Não foram afetados & & & & & 1 & 3,12 & 2 & 20 & 1 & 12,5 & \\
\hline $\begin{array}{l}\text { Q2. No ano passado, as farmácias e/ou os } \\
\text { pontos de venda especializados cobravam } \\
\text { por uma caixa de máscaras, } 50 \text { uni. tripla c/ } \\
\text { elástico, R } \$ 4,50 \text {. Após a crise e disseminação } \\
\text { da Covid-19, a mesma caixa de máscaras, } 50 \\
\text { uni. tripla c/ elástico custa } R \$ 82,50 \text {. } 0 \text { que } \\
\text { você acha dos preços cobrados pela caixa de } \\
\text { máscaras triplas c/ elástico nesse período de } \\
\text { crise e disseminação da Covid-19? }\end{array}$ & & & & & & & & & & & \\
\hline Muito Justo & \multirow[t]{2}{*}{1} & \multirow[t]{2}{*}{2,86} & 2 & 3,45 & 1 & 3,23 & & & & & \\
\hline Justo & & & 6 & 10,34 & 4 & 12,9 & & & & & \\
\hline Indiferente & \multirow{5}{*}{$\begin{array}{l}1 \\
15 \\
18\end{array}$} & \multirow{4}{*}{$\begin{array}{c}2,86 \\
42,86 \\
51,43\end{array}$} & \multirow{4}{*}{$\begin{array}{c}1 \\
16 \\
33\end{array}$} & \multicolumn{2}{|l|}{1,72} & & 1 & \multirow{3}{*}{$\begin{array}{l}10 \\
30 \\
60\end{array}$} & \multirow{3}{*}{$\begin{array}{l}2 \\
2 \\
4\end{array}$} & \multirow{3}{*}{$\begin{array}{l}25 \\
25 \\
50\end{array}$} & \\
\hline Injusto & & & & 27,59 & 7 & 22,6 & 3 & & & & \\
\hline Muito Injusto & & & & 56,9 & 19 & 61,3 & 6 & & & & \\
\hline $\begin{array}{l}\text { Q3. No ano passado, as farmácias e/ou os } \\
\text { pontos de venda especializados cobravam } \\
\text { por } 420 \mathrm{ml} \text { de álcool gel } 70 \text { o valor de R\$ } \\
12,00 \text {. Após a crise e disseminação da Covid- } \\
\text { 19, o mesmo frasco de álcool gel } 70 \text { está } \\
\text { custando R } \$ 45,00 \text {. O que você acha em } \\
\text { relação aos preços cobrados pelo álcool gel } \\
70 \text { nesse período de crise e disseminação da } \\
\text { Covid-19? }\end{array}$ & & & & & & & & & & & 0,336 \\
\hline Muito Justo & & & 1 & 2,85 & 1 & 3,12 & & & & & \\
\hline Justo & 2 & 5,71 & 6 & 10,16 & 4 & 12,5 & & & & & \\
\hline Indiferente & 4 & 11,42 & 1 & 2,85 & & & & & 1 & 12,5 & \\
\hline Injusto & 9 & 25,71 & 17 & 28,81 & 11 & 34,4 & 4 & 40 & 4 & 50 & \\
\hline Muito Injusto & 20 & 57,14 & 34 & 57,62 & 16 & 50 & 6 & 60 & 3 & 37,5 & \\
\hline $\begin{array}{l}\text { Q4. Como você age em relação as empresas } \\
\text { que aumentaram os preços de seus produtos } \\
\text { nesse período de crise e disseminação da } \\
\text { Covid -19? }\end{array}$ & & & & & & & & & & & 0,869 \\
\hline Compro os produtos normalmente & 2 & 5,71 & 3 & 5,17 & 1 & 3,23 & & & 1 & 12,5 & \\
\hline
\end{tabular}




\begin{tabular}{|c|c|c|c|c|c|c|c|c|c|c|c|}
\hline $\begin{array}{l}\text { Procuro um produto similar de uma empresa } \\
\text { concorrente }\end{array}$ & 33 & 94,83 & 55 & 94,83 & 30 & 96,8 & 10 & 100 & 7 & 87,5 & \\
\hline $\begin{array}{l}\text { Q5. Você daria preferência a uma empresa } \\
\text { que faz promoções e/ou vende seus produtos } \\
\text { mais baratos nesse período de crise e } \\
\text { disseminação da Covid-19? }\end{array}$ & \multirow{4}{*}{35} & \multirow{4}{*}{100} & \multirow{4}{*}{$\begin{array}{c}57 \\
1\end{array}$} & \multirow{4}{*}{$\begin{array}{c}98,28 \\
1,72\end{array}$} & \multirow{4}{*}{$\begin{array}{c}30 \\
1\end{array}$} & \multirow{4}{*}{$\begin{array}{l}96,8 \\
3,32\end{array}$} & \multirow{4}{*}{10} & \multirow{4}{*}{100} & \multirow{4}{*}{8} & \multirow{4}{*}{100} & \multirow{4}{*}{$\begin{array}{c}0,94 \\
0,627\end{array}$} \\
\hline Sim & & & & & & & & & & & \\
\hline Não & & & & & & & & & & & \\
\hline $\begin{array}{l}\text { Q6. Após a crise e disseminação da Covid-19, } \\
\text { você continuaria adquirindo produtos de } \\
\text { empresas que aumentaram os preços de seus } \\
\text { produtos no momento da crise e } \\
\text { disseminação da covid-19? }\end{array}$ & & & & & & & & & & & \\
\hline Sim & \multirow{3}{*}{$\begin{array}{l}16 \\
19\end{array}$} & \multirow{3}{*}{$\begin{array}{l}45,71 \\
54,28\end{array}$} & \multirow{3}{*}{$\begin{array}{l}22 \\
36\end{array}$} & \multirow{3}{*}{$\begin{array}{l}38,71 \\
61,29\end{array}$} & \multirow{3}{*}{$\begin{array}{l}12 \\
19\end{array}$} & \multirow{3}{*}{$\begin{array}{l}37,9 \\
62,1\end{array}$} & \multirow{3}{*}{$\begin{array}{l}2 \\
8\end{array}$} & \multirow{3}{*}{$\begin{array}{l}20 \\
80\end{array}$} & \multirow{3}{*}{$\begin{array}{l}4 \\
4\end{array}$} & \multirow{3}{*}{$\begin{array}{l}50 \\
50\end{array}$} & \\
\hline Não & & & & & & & & & & & \\
\hline $\begin{array}{l}\text { Q7. Após a crise e disseminação da Covid-19, } \\
\text { você teria preferência em adquirir produtos } \\
\text { de empresas que baixaram os preços de seus } \\
\text { produtos no momento da crise e } \\
\text { disseminação da covid-19? }\end{array}$ & & & & & & & & & & & 0,435 \\
\hline Sim & 35 & 100 & 54 & 93,1 & 27 & 87,1 & 8 & 80 & 7 & 87,5 & \\
\hline Não & & & 4 & 6,9 & 4 & 12,9 & 2 & 20 & 1 & 12,5 & \\
\hline $\begin{array}{l}\text { Q8. Após a crise e disseminação da Covid-19, } \\
\text { você teria preferência em adquirir produtos } \\
\text { de empresas que aumentaram os preços de } \\
\text { seus produtos no momento da crise e } \\
\text { disseminação da covid-19? }\end{array}$ & & & & & & & & & & & 0,984 \\
\hline Sim & 3 & 8,57 & 5 & 8,62 & 3 & 9,68 & & & & & \\
\hline Não & 32 & 91,43 & 53 & 91,38 & 28 & 90,3 & 10 & 100 & 8 & 100 & \\
\hline $\begin{array}{l}\text { Q9. Se você fosse dono de uma empresa, no } \\
\text { período de crise e disseminação da Covid-19, } \\
\text { em relação aos bens de primeira } \\
\text { necessidade, você reduziria os preços dos } \\
\text { produtos da sua empresa, reduzindo, assim, } \\
\text { seu lucro? }\end{array}$ & & & & & & & & & & & 0,755 \\
\hline Sim & 22 & 62,85 & 45 & 76,27 & 20 & 62,5 & 8 & 80 & 5 & 62,5 & \\
\hline Não & 13 & 37,14 & 14 & 23,72 & 12 & 37,5 & 2 & 20 & 3 & 37,5 & \\
\hline $\begin{array}{l}\text { Q10. Como você agirá, após o término do } \\
\text { período de crise e disseminação da Covid-19, } \\
\text { em relação as empresas que nesse período } \\
\text { aumentaram o preço dos seus produtos? }\end{array}$ & & & & & & & & & & & 0,599 \\
\hline $\begin{array}{l}\text { Continuarei comprando os produtos dessas } \\
\text { empresas normalmente }\end{array}$ & 19 & 54,28 & 24 & 41,38 & 11 & 35,5 & 4 & 40 & 4 & 50 & \\
\hline $\begin{array}{l}\text { Pararei de comprar os produtos dessas } \\
\text { empresas }\end{array}$ & 16 & 45,71 & 34 & 58,62 & 20 & 64,3 & 6 & 60 & 4 & 50 & \\
\hline Teste Qui-quadrado & & & & & & & & & & & \\
\hline
\end{tabular}

Tabela 5

Associação entre as respostas do questionário em relação a faixa etária dos participantes

\begin{tabular}{|c|c|c|c|c|c|c|c|c|}
\hline \multirow[t]{2}{*}{ Variáveis } & $\begin{array}{c}18 \text { a } 25 \\
\text { anos }\end{array}$ & $\begin{array}{c}26 \text { a } 30 \\
\text { anos }\end{array}$ & $\begin{array}{c}31 \text { a } 40 \\
\text { anos }\end{array}$ & \multicolumn{2}{|c|}{$\begin{array}{c}41 \text { a } 50 \\
\text { anos }\end{array}$} & \multicolumn{2}{|c|}{$\begin{array}{c}\text { Acima de } \\
50 \text { anos }\end{array}$} & \multirow{2}{*}{$\begin{array}{c}\text { Valor - } \\
\mathbf{p}\end{array}$} \\
\hline & $\%$ & $\%$ & $\%$ & $\mathbf{n}$ & $\%$ & $\mathbf{n}$ & $\%$ & \\
\hline $\begin{array}{l}\text { Q1. Na sua opinião, seus hábitos de } \\
\text { consumo após a estipulação da } \\
\text { quarentena foram afetados? }\end{array}$ & & & & & & & & 0,952 \\
\hline
\end{tabular}




\begin{tabular}{|c|c|c|c|c|c|c|c|c|c|c|c|}
\hline Muito afetados & 22 & 28,95 & 9 & 33,33 & 7 & 46,67 & 3 & 37,5 & 6 & 37,5 & \\
\hline Afetados & 39 & 51,32 & 10 & 37,04 & 7 & 46,67 & 3 & 37,5 & 7 & 43,75 & \\
\hline Pouco Afetados & 13 & 17,11 & 7 & 25,93 & & & 2 & 25 & 2 & 12,5 & \\
\hline Não foram afetados & 2 & 2,63 & 1 & 3,7 & 1 & 6,67 & & & 1 & 6,25 & \\
\hline $\begin{array}{l}\text { Q2. No ano passado, as farmácias e/ou } \\
\text { os pontos de venda especializados } \\
\text { cobravam por uma caixa de máscaras, } \\
50 \text { uni. tripla c/ elástico, R } \$ 4,50 \text {. Após a } \\
\text { crise e disseminação da Covid-19, a } \\
\text { mesma caixa de máscaras, } 50 \text { uni. tripla } \\
\text { c/ elástico custa } \$ \text { R } 82,50.0 \text { que você } \\
\text { acha dos preços cobrados pela caixa de } \\
\text { máscaras triplas c/ elástico nesse } \\
\text { período de crise e disseminação da } \\
\text { Covid-19? }\end{array}$ & & & & & & & & & & & 0,493 \\
\hline Muito Justo & 4 & 5,26 & & & & & & & & & \\
\hline Justo & 7 & 9,21 & 1 & 3,7 & 2 & 13,33 & & & & & \\
\hline Indiferente & 3 & 3,95 & 1 & 3,7 & & & & & 1 & 6,25 & \\
\hline Injusto & 30 & 39,47 & 8 & 29,63 & 2 & 13,33 & & & 3 & 18,75 & \\
\hline Muito Injusto & 32 & 42,11 & 17 & 62,96 & 11 & 73,33 & 8 & 100 & 12 & 75 & \\
\hline $\begin{array}{l}\text { Q3. No ano passado, as farmácias e/ou } \\
\text { os pontos de venda especializados } \\
\text { cobravam por } 420 \text { ml de álcool gel } 70 \text { o } \\
\text { valor de } \mathrm{R} \$ 12,00 \text {. Após a crise e } \\
\text { disseminação da Covid-19, o mesmo } \\
\text { frasco de álcool gel } 70 \text { está custando } \\
\mathrm{R} \$ 45,00.0 \text { que você acha em relação } \\
\text { aos preços cobrados pelo álcool gel } 70 \\
\text { nesse período de crise e disseminação } \\
\text { da Covid-19? }\end{array}$ & & & & & & & & & & & 0,667 \\
\hline Muito Justo & 2 & 2,63 & & & & & & & & & \\
\hline Justo & 9 & 11,84 & 3 & 11,11 & 1 & 6,67 & & & & & \\
\hline Indiferente & 5 & 6,58 & & & & & & & & & \\
\hline Injusto & 27 & 35,53 & 10 & 37,04 & 3 & 20 & 1 & 12,5 & 3 & 18,75 & \\
\hline Muito Injusto & 33 & 43,42 & 14 & 51,85 & 11 & 73,33 & 7 & 87,5 & 13 & 81,25 & \\
\hline $\begin{array}{l}\text { Q4. Como você age em relação as } \\
\text { empresas que aumentaram os preços de } \\
\text { seus produtos nesse período de crise e } \\
\text { disseminação da Covid -19? }\end{array}$ & & & & & & & & & & & 0,925 \\
\hline Compro os produtos normalmente & 5 & 6,58 & 2 & 7,41 & & & & & & & \\
\hline $\begin{array}{l}\text { Procuro um produto similar de uma } \\
\text { empresa concorrente }\end{array}$ & 71 & 93,42 & 25 & 92,59 & 15 & 100 & 8 & 100 & 16 & 100 & \\
\hline $\begin{array}{l}\text { Q5. Você daria preferência a uma } \\
\text { empresa que faz promoções e/ou vende } \\
\text { seus produtos mais baratos nesse } \\
\text { período de crise e disseminação da } \\
\text { Covid-19? }\end{array}$ & & & & & & & & & & & 0,904 \\
\hline Sim & 75 & 1,32 & 26 & 3,7 & 15 & 100 & 8 & 100 & 16 & 100 & \\
\hline Não & 1 & 98,68 & 1 & 96,3 & & & & & & & \\
\hline $\begin{array}{l}\text { Q6. Após a crise e disseminação da } \\
\text { Covid-19, você continuaria adquirindo } \\
\text { produtos de empresas que aumentaram } \\
\text { os preços de seus produtos no } \\
\text { momento da crise e disseminação da } \\
\text { covid-19? }\end{array}$ & & & & & & & & & & & 0,001 \\
\hline Sim & 42 & 55,26 & 7 & 25,93 & 4 & 26,67 & 1 & 12,5 & 2 & 12,5 & \\
\hline
\end{tabular}




\begin{tabular}{|c|c|c|c|c|c|c|c|c|c|c|c|}
\hline Não & 34 & 44,74 & 20 & 74,07 & 11 & 73,33 & 7 & 87,5 & 14 & 87,5 & \\
\hline $\begin{array}{l}\text { Q7. Após a crise e disseminação da } \\
\text { Covid-19, você teria preferência em } \\
\text { adquirir produtos de empresas que } \\
\text { baixaram os preços de seus produtos no } \\
\text { momento da crise e disseminação da } \\
\text { covid-19? }\end{array}$ & \multirow{4}{*}{$\begin{array}{c}69 \\
7\end{array}$} & \multirow{4}{*}{$\begin{array}{c}90,79 \\
9,21\end{array}$} & \multirow{4}{*}{$\begin{array}{c}23 \\
4\end{array}$} & \multirow{4}{*}{$\begin{array}{l}85,19 \\
14,81\end{array}$} & \multirow{4}{*}{15} & \multirow{4}{*}{100} & \multirow{4}{*}{8} & \multirow{4}{*}{100} & \multirow{5}{*}{16} & \multirow{4}{*}{100} & \multirow{5}{*}{$\begin{array}{l}0,668 \\
0,439\end{array}$} \\
\hline Sim & & & & & & & & & & & \\
\hline Não & & & & & & & & & & & \\
\hline $\begin{array}{l}\text { Q8. Após a crise e disseminação da } \\
\text { Covid-19, você teria preferência em } \\
\text { adquirir produtos de empresas que } \\
\text { aumentaram os preços de seus } \\
\text { produtos no momento da crise e } \\
\text { disseminação da covid-19? }\end{array}$ & & & & & & & & & & & \\
\hline Sim & \multirow{3}{*}{$\begin{array}{c}7 \\
69\end{array}$} & 9,21 & 2 & 7,41 & & & 2 & 25 & & & \\
\hline Não & & \multirow{2}{*}{90,79} & \multirow[t]{2}{*}{25} & \multirow[t]{2}{*}{92,59} & \multirow[t]{2}{*}{15} & \multirow[t]{2}{*}{100} & \multirow[t]{2}{*}{6} & \multirow[t]{2}{*}{75} & \multirow[t]{2}{*}{16} & \multirow[t]{2}{*}{100} & \\
\hline $\begin{array}{l}\text { Q9. Se você fosse dono de uma empresa, } \\
\text { no período de crise e disseminação da } \\
\text { Covid-19, em relação aos bens de } \\
\text { primeira necessidade, você reduziria os } \\
\text { preços dos produtos da sua empresa, } \\
\text { reduzindo, assim, seu lucro? }\end{array}$ & & & & & & & & & & & 0,798 \\
\hline Sim & 49 & 64,47 & 20 & 74,07 & 9 & 60 & \multirow[t]{3}{*}{8} & \multirow[t]{3}{*}{100} & 11 & 68,75 & \\
\hline Não & \multirow[t]{2}{*}{27} & \multirow[t]{2}{*}{35,53} & \multirow[t]{2}{*}{7} & \multirow[t]{2}{*}{25,93} & \multirow[t]{2}{*}{6} & \multirow[t]{2}{*}{40} & & & \multirow[t]{2}{*}{5} & \multirow[t]{2}{*}{31,25} & \\
\hline $\begin{array}{l}\text { Q10. Como você agirá, após o término } \\
\text { do período de crise e disseminação da } \\
\text { Covid-19, em relação as empresas que } \\
\text { nesse período aumentaram o preço dos } \\
\text { seus produtos? }\end{array}$ & & & & & & & & & & & 0,007 \\
\hline $\begin{array}{l}\text { Continuarei comprando os produtos } \\
\text { dessas empresas normalmente }\end{array}$ & 43 & 56,58 & 11 & 40,74 & 3 & 20 & 2 & 25 & 3 & 18,75 & \\
\hline $\begin{array}{l}\text { Pararei de comprar os produtos dessas } \\
\text { empresas }\end{array}$ & 33 & 43,42 & 16 & 59,26 & 12 & 80 & 6 & 75 & 13 & 81,25 & \\
\hline Teste Qui-quadrado & & & & & & & & & & & \\
\hline
\end{tabular}

\section{DISCUSSÃO}

A crise sanitária decorrente do espraiamento da SARS-CoV-2, com repercussões mundiais, que começou localmente e se agravou a ponto de resultar em uma crise sanitária generalizada e mundial, trauxe consigo, no ano de 2020, novas perspectivas às comunidades no mundo inteiro.

De acordo com Malloy-diniz et al. (2020, p.4) "a percepção de risco inerente ao anúncio de uma pandemia pode desencadear mudanças cognitivas emocionais que preparam os indivíduos para a autoproteção". O comportamento comunitário mostrou-se uma necessidade, assim como um dos elementos cruciais para evitar o aumento no número de casos da Covid-19 e suas complicações que, em muitos dos casos, resultam na morte dos contaminados (Lima et al., 2020).

Essa necessidade de uma resposta individual e coletiva mais consciente e solidária pode ser considerada como uma hipótese à influenciar nas percepções e aspirações dos agentes econômicos. Dado que a economia comportamental assume, em suas análises, as peculiaridades da complexidade cognitiva humana, para Bolton e Ockenfels (2000), as pessoas teriam uma propensão a contribuírem umas com as outras, em virtude do histórico humano de formação em comunidades primitivas, nas quais o sucesso do grupo se mostrava como uma variável dependente do sucesso individual.

Isso posto, com a implementação, nos primeiros meses de 2020, da quarentena generalizada, a partir da amostra obtida, encontramos evidências que comprovam que os hábitos de consumo das pessoas sofreram alterações, em que $46,5 \%$ dos respondentes afirmaram que com a implementação da 
quarentena (resposta ao espraiamento da Covid-19) seus hábitos de consumo haviam sido afetados, e $32,6 \%$ informaram que haviam sido muito afetados. Aproximadamente, $79,1 \%$ dos respondentes tiveram seus hábitos de consumo, em algum nível, afetados durante a quarentena.

Dessa forma, os consumidores foram levados a priorizar o consumo de itens considerados essenciais e de proteção pela WHO. As empresas que forneciam tais produtos obtiveram um maior poder de determinação de preços, em razão do aumento da demanda desses bens, no curto prazo.

Na questão Q2, 56,3\% ( $n=80)$ dos respondentes consideraram muito injusto a mudança nos preços da caixa de máscaras (de 50 unidades, tripla c/ elástico), que ocorreu nas farmácias e/ou nos pontos de venda especializados no período de crise e disseminação da Covid-19, seguido pelos que acharam, apenas, injusto, representando 30,3\% $(n=43)$. Somando-se os respondentes que consideraram muito injusto e injusto o cenário proposto na Q2, temos que, aproximadamente, $87 \%$ dos respondentes da pesquisa aplicada consideraram o aumento de preço da caixa de máscaras (de 50 unidades, tripla c/ elástico), em alguma medida, injusta.

Os resultados obtidos na questão Q3 apresentam similaridades com os da questão Q2, embora o bem analisado seja diferente, álcool gel 70 (de $420 \mathrm{ml}$ ). Dessa forma, 54,9\% (n=78) dos respondentes consideraram o aumento de preços muito injusto, seguido pelos que consideraram o aumento de preço injusto, 31\% ( $\mathrm{n}=43)$. Somando-se os respondentes que acharam o aumento de preço do álcool gel 70 (de $420 \mathrm{ml}$ ) muito injusto e injusto, temos que, aproximadamente, 86\% dos respondentes, em alguma medida, ser injusto esse ajustamento de preço no período de crise e disseminação da covid- 19.

Esses resultados estão de acordo com o resultado encontrado no estudo de Kahneman et al. (1986a) em que foi apontado que apesar de a análise econômica convencional assumir como natural o excesso de demanda por um bem criar uma oportunidade para os fornecedores aumentarem os preços de seus produtos, a noção de justiça ou "fairness" está presente nos consumidores e, assim sendo, esta poderá ser um importante fator de modo a afetar o comportamento de compra destes, e, portanto, a sua tomada de decisão.

Dessa forma, tanto no estudo de Kahneman et al. (1986a) quanto no nosso, encontrou-se que as pessoas tendem a agir do modo que acham justo, foi possível concluir que estas, também, esperam que os outros agentes, no mercado, também ajam de forma justa. Sendo assim, avaliação dos consumidores seria injusto as empresas tirarem vantagem do seu poder de mercado para aplicar preços maiores em produtos, os quais, a demanda aumentou em virtude de uma crise sanitária de proporções mundiais.

Nas respostas referentes à questão Q4, foi perguntado aos respondentes como eles agiriam em relação às farmácias e/ou pontos de venda especializados que aumentaram os preços dos seus produtos no período de crise e disseminação da Covid-19. Os dados coletados mostraram que 95,07\% $(n=135)$ optariam por procurar um produto similar de uma empresa concorrente, enquanto que, apenas, 4,93\% $(n=7)$ continuariam comprando os produtos normalmente. A existência de produtos similares ou concorrentes de mercado aumenta as chances do consumidor de "punir" a alta de preço aplicada por alguns ofertantes, no caso de não ser uma alta de preços generalizada.

Entretanto, de acordo com Kahneman et al. (1986a), na medida em que as firmas e os seus concorrentes alteram seus preços, mudando, portanto, o anterior termo de transação de seus produtos, são estabelecidas novas posições referenciais para as transações, relativas ao aumento de preços. Mesmo que estes aumentos não sejam justificados por um aumento nos custos das firmas, aumentos nos preços dos produtos serão menos questionáveis caso os concorrentes aumentem seus preços primeiro.

No que concerne ao posicionamento dos respondentes do questionário referente a uma firma que praticaria uma redução de preços via promoção, relativo à questão Q5, 98,6\% (n=140) dos respondentes dariam preferência a firmas que fazem promoções e/ou vende seus produtos mais baratos nesse período de crise e disseminação da covid 19.

Como no estudo de (Thaler, 1999b), nota-se que, no curto prazo, os respondentes, apresentaram uma sensibilidade em relação aos preços aplicados. Dessa forma, os respondentes estariam dispostos a adquirir produtos de empresas que fizessem algum tipo de redução nos valores de seus produtos, por exemplo, via promoção, o que pode ser debatido focando nos vieses 
representativos da contabilidade mental, dado que "bônus", promoções, brindes aguçam a percepção dos consumidores quanto as relações de compra.

Na questão Q7, dá-se ao respondente uma perspectiva de longo prazo, em que é analisado se estes teriam preferência em adquirir produtos de empresas baseado na atitude destas em relação aos seus preços aplicados, no período de crise e disseminação da Covid-19. Sendo assim, 92,2\% (n=131) teriam preferência em adquirir os produtos de empresas que, após a crise e disseminação da Covid 19, baixaram seus preços no momento da crise e disseminação da Covid-19.

Na questão Q8, quando perguntado aos respondentes se estes teriam preferência em adquirir, após a crise e disseminação da Covid-19, produtos de empresas que aumentaram seus preços no momento da crise e disseminação da covid-19, 92,2\% (n=131) afirmaram que não, e 7,8\% (n=11) responderam que sim.

Os dados explanados acima reforçam a análise de Fehr e Schmidt (2003), de que embora haja evidências empíricas que sustentem que os agentes econômicos, em muitos assuntos, se comportam, de fato, com uma atitude completamente egoísta, mesmo em situações em que estes têm a chance de afetar o bem estar alheio a um custo relativamente pequeno, existiriam pessoas que seriam motivadas pelo sentimento de justiça e reciprocidade, sendo estas dispostas a recompensar ou punir a outros mesmo que para isso, sofram um custo maior para si mesmas.

Assim, discorre Shefrin (2003) que os mercados são eficientes na medida em que os preços coincidem com o valor intrínseco do produto, e de acordo com Bolton e Ockenfels 2000) e Fehr e Schmidt (2003), apesar das consistências apresentadas nos estudos empíricos a respeito do comportamento dos mercados, em relação ao espírito competitivo e às noções do interesse individualista dos agentes econômicos, nas transações, grande parte dos experimentos também mostram que nas relações de trocas, condutas, se dão a partir de parâmetros como equidade e reciprocidade.

Todavia, em Pindyck e Rubinfeld (2006), no caso da análise de longo prazo, a lógica psicológica dos consumidores relativa aos preços pode ser uma variável dinâmica, e não estática, ou seja, que o senso de "justiça" pode ser passível de alteração ao longo do tempo, podendo, portanto, sofrer um processo de adaptação, em que o preço, que outrora parecia 'injusto', na concepção do consumidor, passaria a ser visto como normal e/ou aceitável.

Nas questões Q6 e Q10, as perguntas são mais diretas, sendo mais explícito a atitude e a disposição do consumidor a punir as empresas que aumentaram o preço dos seus produtos no período de crise e disseminação da covid-19, com resultados similares e consistentes, a partir das similaridades das questões. No longo prazo, após a crise e disseminação da covid 19, os entrevistados estariam dispostos a "punir" as empresas que aumentaram o preço de seus produtos nesse período.

A questão Q9, no tocante a como os respondentes agiriam, caso fossem eles(as) os ofertantes dos bens, $68,1 \%(\mathrm{~N}=98)$ reduziriam os preços dos seus produtos mesmo com um possível decrescimento no lucro. Apesar da ciência econômica ter uma atitude neutra em relação às análises éticas (Kahneman et al., 1986a), os respondentes, ao serem colocados no lugar dos ofertantes, teriam, em sua maioria, uma atitude na qual tratariam os consumidores na forma que gostariam de ser tratados.

\section{Associação das variáveis}

$\mathrm{Na}$ Tabela 3, temos os dados que fazem referência a associação entre as respostas do questionário em relação ao gênero dos participantes da pesquisa. É possível constatar que há evidências de associação entres a variável gênero e as questões Q2 ( $p=0,044)$ e Q3 ( $p=0,084)$, de modo que o gênero feminino apresenta uma maior porcentagem de respondentes que acham injusto $(32,47 \%)$ e muito injusto $(62,34 \%)$ a mudança de preços tanto da caixa de máscaras (Q2) quanto do álcool em gel $70(\mathrm{Q} 3)$. A questão Q4 $(\mathrm{P}=0,029)$ também se mostrou com evidência de associação com a variável gênero, em que é analisada a forma com que o respondente age em relação às empresas que aumentaram os seus preços, tendo, portanto, uma maior porcentagem de respondentes do gênero feminino $(98,7 \%)$ comparativamente ao masculino, que está disposto a procurar um produto similar em uma empresa concorrente $(90,76 \%)$. 
0 gênero não necessariamente seria um determinante quanto à procura ou não de produtos similares aos dos produtos que aumentaram seus preços, o que mostra uma tendência de não continuidade da compra destes produtos independente do gênero.

Além disso, mostrou-se estatisticamente relevante a associação da variável gênero em relação às questões $\mathrm{Q} 7(\mathrm{p}=0,061)$ e $\mathrm{Q} 8(\mathrm{p}=0,061)$, de modo que, referente à questão $\mathrm{Q7}$, uma maior parcela do gênero feminino $(96,1 \%)$ comparativamente ao masculino $(87,69 \%)$ estaria disposta a, após a crise e disseminação da Covid-19, dar preferência a adquirir produtos de empresas que baixaram seus preços no momento da crise. Já em relação à questão Q8, os respondentes do gênero feminino $(96,1 \%)$ em relação ao masculino (87,69\%), após a crise e disseminação da Covid-19, não teriam preferência em adquirir produtos de empresas que aumentaram seus preços nesse período (Tabela 3 )

No caso da associação de variáveis em relação à renda, na Tabela 4, mostrou-se evidência de associação entre variáveis a questão Q1 ( $\mathrm{p}=0,058)$, dado que a pandemia afetou os hábitos de consumo dos respondentes, de modo que, aproximadamente, $96,47 \%$ destes responderam que foram de alguma forma afetados após a estipulação da quarentena. Nesse particular, a maior porcentagem de respondentes que foi afetada encontra-se na faixa de renda de três a seis salários mínimos (69\%), seguido pelos de um a três salários mínimos (46\%).

No que concerne à associação de variáveis em relação à idade, mostrada na Tabela 5, há evidências de associação na questão Q6 $(\mathrm{p}=0,001)$, em que quanto maior a faixa etária, maior a porcentagem de respondentes que não continuariam, após a crise e disseminação da Covid-19, a comprar os produtos de empresas que aumentaram seus preços nesse período, sendo, portanto, os acima de 50 anos $(87,5 \%)$ e os de 41 a 50 anos $(87,5 \%)$, de maior percentual.

Os da faixa etária de 18 a 25 anos (55,26\%), mostraram-se dispostos a continuar comprando os produtos de empresas que aumentaram os seus preços no momento da crise. Nessa faixa etária, os que não continuariam comprando correspondeu a um percentual menor, relativamente, de 44,74\%, sendo esse o único intervalo de faixa etária em que os respondentes tiveram uma porcentagem maior a favor da continuidade da compra de produtos de empresas que aumentaram seus preços após a crise e disseminação da covid-19.

Ainda, na Tabela 5, a questão Q10 ( $\mathrm{p}=0,007)$ mostrou-se estatisticamente relevante na associação com a faixa etária dos respondentes, de modo que, semelhante à questão Q6, na questão Q10, os respondentes de menor faixa etária, 18 a 25 anos (56,58\%) mostraram-se em maior proporção a agir de maneira a continuar comprando os produtos das empresas que nesse período aumentaram os preços de seus produtos.

Embora as outras faixas etárias apresentassem, em maior proporção, respostas de modo a punir essas empresas. Como exemplo, os respondentes da faixa etária acima de 50 anos, 81,25\% destes parariam de comprar os produtos dessas empresas.

Fehr e Schmidt (2003) assumem que as evidências dos testes empíricos mostram que os consumidores, para além da maximização da sua recompensa material, estão também preocupados com o desejo de reciprocidade, justiça e justiça social.

\section{CONSIDERAÇÕES FINAIS}

Neste estudo, apresentamos uma nova perspectiva para as análises da interação entre oferta e demanda na economia, em que o consumidor como agente econômico, age de forma para além das hipóteses de racionalidade determinadas pelos modelos canônicos, e interage de modo a "punir", as empresas que aplicaram um aumento dos seus preços no período de crise e disseminação da covid-19, e como o sentimento de "justiça" por parte dos consumidores pode afetar as perspectivas de lucro dessas empresas no curto e no longo prazo.

Desse modo, apresentamos achados relevantes quanto à percepção dos consumidores, sendo possível, a partir da amostra analisada, concluir que as circunstâncias, ou seja, o contexto no qual as pessoas estão inseridas influenciam na percepção destes e na sua disposição quanto a "punir" empresas que, no período de crise e disseminação da covid- 19 tiveram uma atitude considerada "injusta" na sua política de preços. Além disso, estariam dispostas a abdicar de um possível incremento 
nos lucros advindos dos aumentos nos preços. Estes achados reforçam as conclusões dos estudos de Kahneman et al. (1986), Fehr e Schmidt (2003) e Thaler (1999b).

Foi possível verificar que uma maior porcentagem dos respondentes da pesquisa entre a faixa de renda de três a seis salários-mínimos foram afetados pela quarentena seguidos pelos da faixa de renda de um a três salários mínimos.

Uma parcela significante do gênero feminino maior em relação ao gênero masculino considerou injusto o aumento de preços dos produtos, além de estar disposta a procurar produtos substitutos para aqueles que sofreram o aumento de preços, sendo, portanto, possível dizer que após a crise e disseminação da covid-19, as pessoas do gênero feminino teriam preferência em adquirir produtos de empresas que baixaram o preço de seus produtos no período da crise.

Além disso, encontramos evidências que quanto maior a faixa etária do indivíduo, mais propenso este estaria de, após a crise e disseminação da covid-19, não adquirir produtos de empresas que aumentaram seus preços no período da crise. À vista disso, os de faixa etária entre 18 a 25 anos mostraram-se mais propensos a continuar a adquirir os produtos de empresas que aumentaram seus preços nesse período. Ademais, a faixa etária de 18 a 25 anos foi a única em que os respondentes tiveram uma porcentagem maior a favor da continuidade da compra, após a crise e disseminação da covid-19, de produtos de empresas que aumentaram seus preços nesse período. Os respondentes da faixa etária acima de 50 anos mostraram-se mais propensos a punir as empresas que aumentaram seus preços nesse período.

$\mathrm{Na}$ associação de variáveis, a partir do recorte por gênero, faixa etária e renda o presente estudo trouxe uma inovação na análise em relação aos estudos de Kahneman et al. (1986a) e Thaler, (1999b), indo mais a fundo em relação às especificidades sóciodemográficas desses consumidores.

Dessa forma, acredita-se que os resultados possam ser empregados em estratégias mercadológicas por parte das empresas em relação a como estas possam se utilizar de políticas de preços de modo a preservar uma relação com os consumidores sem sofrerem punições por parte destes, no curto e no longo prazo. Encoraja-se a replicação do estudo em outros cenários de investigação, com uma amostra maior, que representou uma limitação na presente pesquisa.

\section{References}

Bchetnia M. et al. (2020). The outbreak of the novel severe acute respiratory syndrome coronavirus 2 (SARS-CoV-2): A review of the current global status. J. Infect Public Health, 13(11), 1601-1610. doi: 10.1016/j.jiph.2020.07.011.

Bolton, Gary E. \& Ockenfels, Axel (2000). ERC: A Theory of Equity, Reciprocity, and Competition. American Economic Review, 90(1), 166-193, vol. 90, No. 1.

Cavalcante, João Roberto et al(2020). COVID-19 no Brasil: evolução da epidemia até a semana epidemiológica 20 de 2020. Epidemiol. Serv. Saude, Brasília.

Cronologia da covid-19 no Brasil: Deutsche Welle (DW), https://www.dw.com/pt-br/cronologiada-covid-19-no-brasil/g-52930927

Hunt, E. K \& Lautzenheiser, M.(2013). História do pensamento econômico. Elsevier: Rio de Janeiro.

Einstein, Albert (1999). A Teoria da Relatividade Espacial e Geral. Contraponto: Rio de Janeiro.

Fehr, Ernst., \& Schmidt, Klaus M. (2003). Theories of Fairness and Reciprocity - Evidence and Economic Applications. Mathias Dewatripont, Lars Peter Hansen and Stephen J Turnovsky: Advances in Economics and Econometrics, Econometric Society Monographs, Eighth World Congress, Vol. 1.

Kahneman, Daniel (2012). Rápido e devagar: duas formas de pensar. Tradução Cássio de Arantes Leite. Editora objetiva LTDA. Rio de Janeiro.

Kahneman, Daniel., Knetsch, Jack L., \& Thaler, Richard. (1986a). Fairness as a Constraint on Profit Seeking: Entitlements in the Market. The American Economic Review, 76(4).

Kahneman, Daniel., Knetsch, Jack L., \& Thaler, Richard. (1986b). Fairness and the Assumptions of Economics. The Journal of Business, 59(4), Part 2: The Behavioral Foundations of Economic Theory. 
Latinne A. et al. (2020). Origin and cross-species transmission of bat coronaviruses in China. Nat Commun, 25;11(1), 4235. doi: 10.1038/s41467-020-17687-3. PMID: 32843626; PMCID: PMC7447761.

Lima, Danilo Ferreira Lopes et al. (2020). COVID-19 no estado do Ceará, Brasil: comportamentos e crenças na chegada da pandemia. Ciência \& Saúde Coletiva.

Lu, R et al. (2020). Genomic characterisation and epidemiology of 2019 novel coronavirus: implications for virus origins and receptor binding. Lancet, 22;395(10224), 565-574. doi: 10.1016/S0140-6736(20)30251-8.

Lvov, DK., \& Alkhovsky, SV. (2020). Source of the COVID-19 pandemic: ecology and genetics of coronaviruses (Betacoronavirus: Coronaviridae) SARS-CoV, SARS-CoV-2 (subgenus Sarbecovirus), and MERS-CoV (subgenus Merbecovirus). Vopr Virusol. Russian, doi: 10.36233/0507-4088-2020-65-2-62-70. PMID: 32515561.

Malloy-diniz, Leandro Fernandes et al. (2020). Saúde mental na pandemia de COVID -19: considerações práticas multidisciplinares sobre cognição, emoção e comportamento. Debates em psiquiatria Ahead of print. Researchgate,

Mattar, F. N. (1994). Pesquisa de marketing: metodologia, planejamento execução e análise. 2ª . Ed. São Paulo: Atlas, 2v., v.2.

Orlando, Giovanna.(2020). Covid-19 satura sistemas de saúde e mundo corre atrás de soluções. R7 notícias.

Pindyck, Robert S., \& Rubinfeld, Daniel L (2006). Microeconomia. Tradução Eleutério Prado, Thelma Guimarães - 6 edição

Rothan, Há \& Byrareddy, SN (2020). The epidemiology and pathogenesis of coronavirus disease (COVID19) outbreak. J Autoimmun.

Shefrin, Hersh (2003). Beyond Greed and Fear: Understanding behavioral finance and the psychology of investing. Oxford Scholarship Online

Shefrin, H. \& Statman, M. (1985). The disposition to sell winners too early and to ride losers too long: theory and evidence. The Journal of Finance, 40(3), 777-790.

Shiller, Robert J. (1998). Human behavior and the efficiency of the financial system. Cowles foundation discussion paper no. 1172; New Haven, Connecticut.

Simonsen, Mario Henrique (1988). Teoria Microeconômica. Instituto de documentação Editora da Fundação Getulio Vargas; volume 1, 9a ed. (pp. 3-6). Rio de Janeiro.

Smith, Vernon L. (2000). Bargaining and Market Behavior: Essays in Experimental Economics. Cambridge University Press.

Thaler, Richard H.(1999a). The End of Behavioral Finance. Financial Analysts Journal, 55(6), Behavioral Finance.

Thaler, Richard H. (1999b) Mental accounting matters. Journal of Behavioral Decision Making, 12, 183206.

Varian, Hal R. (2006). Microeconomia: conceitos básicos. Tradução Maria José Cyhlar Monteiro e Ricardo Donielle, Elsevier 7 a edição

Weber, Max (2004). A ética protestante e o "espírito" do capitalismo. Edição de Antônio Flávio Pierucci; Companhia das letras.

Wold Health Organization (2020). Considerations for implementing and adjusting public health and social measures in the context of COVID-19. Interim guidance. COVID-19: Critical preparedness, readiness and response.

$\mathrm{Xu}, \mathrm{Z}$. et al. (2020). Pathological findings of COVID-19 associated with acute respiratory distress syndrome. Lancet Respir.

Notas de rodapé

1"uma proposição é correta ou "verdadeira" quando é derivada dos axiomas da maneira geralmente aceita [...] A questão da "verdade" [...] nos leva, portanto, de volta à questão da "verdade" dos axiomas". (Einstein, 1999, p.11) 
${ }^{2}$ De acordo com dados disponíveis na plataforma eletrônica do Senado Federal do Brasil, o salário mínimo no ano de 2020 no Brasil correspondia ao valor de R\$ 1045,00/mês.: <https://www12.senado.leg.br/noticias/materias/2021/01/04/ja-esta-em-vigor-novo-salario-minimode-r-

1.100\#: :text=Em\%2031\%20de\%20dezembro\%20de,foi\%20ajustado\%20para\%20R\%24\%201.045.>

\section{Apêndice A - Instrumento de coleta de dados}

\section{QUESTIONÁRIO}

Q1 - Na sua opinião, seus hábitos de consumo após a estipulação da quarentena foram afetados?

( ) Muito Afetados ( ) Pouco Afetados

( ) Afetados ( ) Não foram afetados

Q2 - No ano passado, as farmácias e/ou os pontos de venda especializados cobravam por uma caixa de máscaras, 50 uni. tripla c/ elástico, $\mathrm{R} \$ 4,50$. Após a crise e disseminação da Covid-19, a mesma caixa de máscaras, 50 uni. tripla c/ elástico custa $\mathrm{R} \$ 82,50$. 0 que você acha dos preços cobrados pela caixa de máscaras triplas c/ elástico nesse período de crise e disseminação da Covid-19?
( ) Muito Justo
( ) Indiferente
() Muito Injusto
( ) Justo
( ) Injusto

Q3 - No ano passado, as farmácias e/ou os pontos de venda especializados cobravam por $420 \mathrm{ml}$ de álcool gel 70 o valor de R\$12,00. Após a crise e disseminação da Covid-19, o mesmo frasco de álcool gel 70 está custando $R \$ 45,00$. 0 que você acha em relação aos preços cobrados pelo álcool gel 70 nesse período de crise e disseminação da Covid-19?
( ) Muito Justo
( ) Indiferente
() Muito Injusto
( ) Justo
( ) Injusto

Q4 - Como você age em relação as empresas que aumentaram os preços de seus produtos nesse período de crise e disseminação da Covid -19?
( ) Compro os produtos normalmente
( ) Procuro um produto similar de uma empresa concorrente

Q5 - Você daria preferência a uma empresa que faz promoções e/ou vende seus produtos mais baratos nesse período de crise e disseminação da Covid-19?
() Sim
( ) Não

Q6 - Após a crise e disseminação da Covid-19, você continuaria adquirindo produtos de empresas que aumentaram os preços de seus produtos no momento da crise e disseminação da covid-19?
() $\operatorname{Sim}$
() Não

Q7 - Após a crise e disseminação da Covid-19, você teria preferência em adquirir produtos de empresas que baixaram os preços de seus produtos no momento da crise e disseminação da covid-19?
() $\operatorname{Sim}$
() Não

Q8 - Após a crise e disseminação da Covid-19, você teria preferência em adquirir produtos de empresas que aumentaram os preços de seus produtos no momento da crise e disseminação da covid19 ?
() $\operatorname{Sim}$ 
( ) Não

Q9 - Se você fosse dono de uma empresa, no período de crise e disseminação da Covid-19, em relação aos bens de primeira necessidade, você reduziria os preços dos produtos da sua empresa, reduzindo, assim, seu lucro?
() $\operatorname{Sim}$
() Não

Q10 - Como você agirá, após o término do período de crise e disseminação da Covid-19, em relação as empresas que nesse período aumentaram o preço dos seus produtos?
() Continuarei comprando os produtos dessas empresas normalmente

() Pararei de comprar os produtos dessas empresas

PERFIL DO ENTREVISTADO

Quantos anos você tem?
( ) $18-25$ ( ) $30-40$ ( ) Acima de 50 anos
( ) $26-30$ ( ) $41-50$

Qual é o seu gênero?

( ) Feminino ( ) Masculino

Quanto é a sua renda?

( ) Menor que 1 salário mínimo ( ) De 3 a 6 salários mínimos ( ) Acima de 10 salários mínimos

( ) De 1 a 3 salários mínimos ( ) De 6 a 10 salários mínimos 